\title{
ARTICLE
}

\section{Self-activation of $\mathrm{V} \gamma \mathrm{V} \delta 2 \mathrm{~T}$ cells by exogenous phosphoantigens involves TCR and butyrophilins}

\author{
Chloé Laplagne ${ }^{1,2,3}$, Laetitia Ligat ${ }^{1,2,3}$, Juliet Foote ${ }^{1,2,3}$, Frederic Lopez ${ }^{1,2,3}$, Jean-Jacques Fournié ${ }^{1,2,3}$, Camille Laurent ${ }^{1,2,3,4}$, \\ Salvatore Valitutti ${ }^{1,2,3}$ and Mary Poupot ${ }^{1,2,3 凶}$
}

(c) The Author(s), under exclusive licence to CSI and USTC 2021

The high cytotoxic activity of Vy $9 \mathrm{~V} \delta 2 \mathrm{~T}$ lymphocytes against tumor cells makes them useful candidates in anticancer therapies. However, the molecular mechanism of their activation by phosphoantigens (PAgs) is not completely known. Many studies have depicted the mechanism of $\mathrm{V} \gamma 9 \mathrm{~V} \delta 2 \mathrm{~T}$-cell activation by PAg-sensed accessory cells, such as immune presenting cells or tumor cells. In this study, we demonstrated that pure resting Vү9V $22 \mathrm{~T}$ lymphocytes can self-activate through exogenous PAgs, involving their TCR and the butyrophilins BTN3A1 and BTN2A1. This is the first time that these three molecules, concurrently expressed at the plasma membrane of $\mathrm{V} y 9 \mathrm{~V} \delta 2 \mathrm{~T}$ cells, have been shown to be involved together on the same and unique $\mathrm{T}$ cell during $\mathrm{PAg}$ activation. Moreover, the use of probucol to stimulate the inhibition of this self-activation prompted us to propose that ABCA-1 could be implicated in the transfer of exogenous PAgs inside Vү9V $\delta 2 \mathrm{~T}$ cells before activating them through membrane clusters formed by $Y 9 T C R, B T N 3 A 1$ and BTN2A1. The self-activation of Vy9V $22 \mathrm{~T}$ cells, which leads to self-killing, can therefore participate in the failure of $\gamma \delta T$ cell-based therapies with exogenous PAgs and should be taken into account.

Keywords: Vү9Vठ2 T cells; Phosphoantigen; Butyrophilins; T-cell receptor

Cellular \& Molecular Immunology (2021) 18:1861-1870; https://doi.org/10.1038/s41423-021-00720-w

\section{INTRODUCTION}

The mediation of cytotoxicity against tumor cells by $\mathrm{V}_{\gamma} 9 \mathrm{~V} \delta 2 \mathrm{~T}$ lymphocytes [1, 2] has been considered as an interesting candidate cancer immunotherapy for several years. Even if these cells represent only $1-3 \%$ of blood mononuclear cells, they can proliferate in vitro and in vivo upon activation and infiltrate the tumor site [2-4]. However, their effects have not been consistent across different studies and different types of malignancies, and their use has resulted in both good $[5,6]$ and bad prognoses $[7,8]$. In addition, no substantial antitumoral activity was detected in clinical trials with Vy9V $\delta 2 \mathrm{~T}$ lymphocyte-based immunotherapies, although weak tumor regression associated with significant amplification of these lymphocytes in the blood was found in a few cases (all reviewed in ref. [9]). These failures can be attributed to the resistance of tumor cells to $\mathrm{V} y 9 \mathrm{~V} \delta 2 \mathrm{~T}$-cell killing and/or the limited understanding of $\mathrm{V} \gamma \mathrm{V} \delta 2 \mathrm{~T}$-cell receptor (TCR) diversity and the mode of action of receptor-ligand interactions.

VY9V82 T cells are activated by nonpeptide phosphoantigens (PAgs), which are metabolites of the methyl erythritol phosphate pathway in microbial pathogens [10] and the eukaryotic mevalonate (MVA) pathway in tumor cells [11, 12]. This PAg activation was clearly shown to be TCR-dependent and possibly modulated by immune checkpoint inhibitors and natural killer (NK) receptors also expressed by $\mathrm{V} \gamma 9 \mathrm{~V} \delta 2 \mathrm{~T}$ cells [13-17]. Moreover, the upregulation of endogenous biosynthesis of PAgs in tumor cells with inhibitors of the MVA pathway, such as aminobisphophonate
$(A B P)$, can exacerbate antitumor $\mathrm{V} y 9 \mathrm{~V} \delta 2 \mathrm{~T}$-cell functions. Even if novel pathways to potentiate the clinical effects of $\mathrm{V} y 9 \mathrm{~V} \delta 2 \mathrm{~T}$ cells were proposed [9], the clarification of some gray areas of PAg activation of these cells remains essential. Although the details of tumor cell recognition can be controversial, members of the butyrophilin A (BTNA) family, BTN3A1 and BTN2A1, were shown to be essential for this recognition, as have the ABCA1 transporter and the intracellular RHOB and periplakin molecules [18-24].

However, direct PAg activation in Vy9V $\delta 2 \mathrm{~T}$ cells, i.e., without an accessory cell and without any cell contact, has never been described. A few years ago, some researchers proposed direct activation of $\mathrm{V} \gamma 9 \mathrm{~V} \delta 2 \mathrm{~T}$ cells by exogenous $\mathrm{PAg}$, while others argued that the small size of these molecules precludes direct activation of the TCR $[25,26]$, but experimental evidence was missing to explain the exact mechanism. In this study, we have shown that pure resting $\mathrm{V} y 9 \mathrm{~V} \delta 2 \mathrm{~T}$ cells from the blood can be directly activated by exogenous PAg but not by ABP in a cell contact-independent manner with a mechanism involving $Y 9 T C R$, BTN2A1, and BTN3A1.

\section{MATERIALS AND METHODS VY9Vס2 T cells}

Untouched fresh $\gamma \delta \mathrm{T}$ cells were obtained from fresh PBMCs from healthy donors using the TCRy $\delta^{+}$T-Cell Isolation Kit, a MidiMACS ${ }^{\text {TM }}$ Separator, and an LS Column, according to the manufacturer's instructions (Miltenyi Biotec, Germany).

${ }^{1}$ Inserm UMR1037, Centre de Recherches en Cancérologie de Toulouse, Toulouse, France. ${ }^{2}$ Université Toulouse III Paul-Sabatier, Toulouse, France. ${ }^{3}$ ERL 5294 CNRS, Toulouse, France. ${ }^{4}$ IUCT-O, Toulouse, France. ${ }^{凶}$ email: mary.poupot@inserm.fr

Received: 30 March 2021 Accepted: 4 June 2021

Published online: 28 June 2021 


\section{Reagents and antibodies}

Reagents. BrHPP (200 nM) and c-HDMAPP ( $2 \mathrm{nM}$, Innate Pharma, Marseille, France); IPP $(10 \mu \mathrm{M})$, zoledronic acid monohydrate (Zometa, 1 or $5 \mu \mathrm{M})$, DAPI $(1 \mu \mathrm{g} / \mathrm{mL})$, and Probucol (10 $\mu \mathrm{M}$, Sigma-Aldrich St. Louis, MO); 7-AAD viability staining solution (Sony Biotechnology).

Flow cytometry antibodies. Anti-CD3 mAb (BV510, clone UCHT1, BD

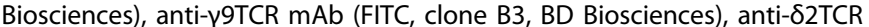
mAb (PE, clone REA771, Miltenyi Biotec), anti- $\gamma \delta T C R ~ m A b$ (BV510, clone B1, Sony Biotechnology), PeCy5 or PE anti-CD107a (clone H4A3), APC-Cy7 antiCD69 (clone FN50), PE anti-BTN3A1 (clone 232-5) and isotopic controls (BD Biosciences); anti-BTN2A1 (Biorbyt, Cambridge, United Kingdom); PeCy7 anti-IFNY (clone B27) and isotype control (Sony Biotechnology).

Activating antibody. Anti-BTN3A activating antibody (clone 20.1, $10 \mu \mathrm{g} / \mathrm{ml})$.

Blocking antibodies. Anti-BTN3A1 $1 \mathrm{~h}$ at $10 \mu \mathrm{g} / \mathrm{mL}$ (103.2) and antiBTN2A1 (7.48, ImCheck Therapeutics, Marseille, France); and anti- $\gamma \delta T C R$ $1 \mathrm{~h}$ at $0.5 \mathrm{mg} / \mathrm{mL}$ (clone B1, BioLegend).

\section{Trogocytosis analysis and cytotoxic assay}

Daudi cells were stained with the lipophilic green-emitting dye PKH67 (Sigma-Aldrich). Pure resting $\gamma \delta T$ cells were stained with PKH67 or with cytoplasmic Cell Tracker ${ }^{\text {TM }}$ Orange-CMTMR [5-(and-6)-(((4-chloromethyl) benzoyl) amino) tetramethylrhodamine), Molecular Probes, Oregon, USA] according to the manufacturer's instructions. CMTMR ${ }^{+} \gamma \delta$ T cells were cocultured with $\mathrm{PKH}_{6} 7^{+}$cells (Daudi cells or autologous $\gamma \delta \mathrm{T}$ cells) at $37^{\circ} \mathrm{C}$ in RPMI 1640 culture medium (Invitrogen, Cergy Pontoise, France) supplemented with $10 \%$ fetal calf serum (Hy1, Thermo Scientific, USA), $100 \mu \mathrm{g} / \mathrm{ml}$ streptomycin, and $100 \mathrm{IU} / \mathrm{ml}$ penicillin (Cambrex Biosciences, Rockland, ME, USA). The cocultures were performed in 96-well U-bottom culture plates at a cell ratio of 1:1 with a total of 200,000 cells per well. CD107a or lgG1 was added to the coculture, and brefeldin A $(10 \mu \mathrm{g} / \mathrm{ml})$ was added after $2 \mathrm{~h}$ of coculture. After $4 \mathrm{~h}$ of coculture, the cells were washed with $0.5 \mathrm{mM}$ PBS/EDTA and then stained with 7-AAD and DAPI to identify dead cells. Trogocytosis was measured as the acquisition of PKH67 fluorescence by $\mathrm{CMTMR}^{+} \gamma \delta \mathrm{T}$ cells, which was characterized by an increase in the mean fluorescence intensity of PKH67 by flow cytometry.

\section{Flow cytometry analysis}

Cells were labeled with the indicated antibodies or isotype controls at $5 \mu \mathrm{g} / \mathrm{ml}$ for $20 \mathrm{~min}$ at $4{ }^{\circ} \mathrm{C}$ and analyzed on an LSRIl cytometer (BD Biosciences, Pont de Claix, France). Data were analyzed using BD FACSDiva software or FlowJo software. Intracellular staining was performed using BD Cytofix Cytoperm according to the manufacturer's instructions (BD Biosciences).

\section{Single-cell calcium video imaging}

To assess the real-time activation of lymphocytes, measurements of the intracellular $\mathrm{Ca}^{2+}$ levels were performed with $\gamma \delta$ T cells loaded with $2 \mu \mathrm{g}$ Fluo-8 AM (Abcam) for $30 \mathrm{~min}$ at $37^{\circ} \mathrm{C}$ in RPMI medium. $\gamma \delta \mathrm{T}$ cells were washed, resuspended in HBSS FCS $1 \%$ and seeded on Angiogenesis $\mu$-Slides (Ibidi, Planegg/Martinsried, Germany) coated with poly-D-lysine for $5 \mathrm{~min}$ at $37^{\circ} \mathrm{C}(10 \mu \mathrm{g} / \mathrm{mL}$, Sigma-Aldrich) and two PBS washes.

үठ T cells were stimulated by BrHPP $(200 \mathrm{nM})$, cHDMAPP $(2 \mathrm{nM})$, IPP $(15 \mu \mathrm{M})$, zoledronate $(1 \mu \mathrm{M})$, or ionomycin $(1 \mu \mathrm{M})$ as indicated. In some experiments, $\gamma \delta$ T cells were previously treated with blocking antibodies for $2 \mathrm{~h}$ (anti-BTN3A1 $10 \mu \mathrm{g} / \mathrm{mL}$, anti-BTN2A1 $10 \mu \mathrm{g} / \mathrm{mL}$ or anti- $\gamma \delta T C R 10 \mu \mathrm{g} / \mathrm{mL}$ ), or with reagent (Probucol $10 \mu \mathrm{M}$ overnight).

Measurements of intracellular $\mathrm{Ca}^{2+}$ responses were performed using a Zeiss LSM 880 FAST Airyscan confocal microscope equipped with a $63 \mathrm{X}$ Plan-Apochromat oil immersion objective with a 1.4 aperture and an incubation system (PeCon-Zeiss) to regulate the temperature $\left(37^{\circ} \mathrm{C}\right)$ and $\mathrm{CO}_{2}(5 \%)$.

To analyze calcium influx, the mean Fluo-8 AM ratio (mean Fluo-8 AM intensity/cell area) in isolated fresh $\gamma \delta$ T cells over time was quantified and reported.

To study the reproducibility of calcium influx, these profiles were applied to several freshly isolated sets of $\gamma \delta \mathrm{T}$ cells, and the results were quantified. This quantification represents the quantitative difference between the maximum and minimum values (5\% standard deviation) of the Fluo-8 AM intensities emitted by an isolated cell for each condition.

\section{Immunofluorescence microscopy and colocalization analysis}

Microscope slides were coated with poly-D-lysine $(10 \mu \mathrm{g} / \mathrm{mL}$, overnight, Sigma-Aldrich). Fresh purified $\gamma \delta T$ cells were previously stained with anti- $\gamma 9$ TCR antibody (FITC, clone B3, BD Biosciences) and anti-BTN3A1 (BV421, clone 232-5, BD Biosciences) for $20 \mathrm{~min}$ at $4{ }^{\circ} \mathrm{C}$. Next, freshly purified $\gamma \delta$ T cells were untreated or treated with $\operatorname{BrHPP}(200 \mathrm{nM})$ for 3 , 10 , or $45 \mathrm{~min}$ or ionomycin $(10 \mathrm{~min}$ at $10 \mu \mathrm{g} / \mathrm{mL})$ under optimal culture conditions $\left(37^{\circ} \mathrm{C}\right.$ and $\left.5 \% \mathrm{CO} 2\right)$. Then, the cells were dropped on slides and fixed with $4 \%$ PFA for 10 min (room temperature). After a blocking incubation of $30 \mathrm{~min}$ (PBS $10 \% \mathrm{SVF}$, room temperature), $\gamma \delta$ T cells were stained overnight at $4{ }^{\circ} \mathrm{C}$ with an anti-BTN2A1 $(5 \mu \mathrm{g} / \mathrm{mL}$, Biorbyt) primary antibody. After three washes, goat anti-rabbit (AF568) secondary antibody was added at $1 \mu \mathrm{g} / \mathrm{mL}$ for $1 \mathrm{~h}$ at room temperature. Finally, slides were mounted with Fluoromount-G mounting medium and analyzed on a Zeiss LSM 780 or 880 FAST Airyscan confocal microscope.

Quantitative colocalization analysis between BTN2A1, BTN3A1, and $\gamma 9 T C R$ on the surface of freshly purified $\gamma \delta$ T cells was achieved on the plot profile with the RGB profiler in ImageJ. For colocalization analysis, we determined Manders' coefficient [27] on median optical sections using ImageJ and the JACoP plug-in.

\section{Statistics}

Data are expressed as the mean \pm SEM. For comparison of two series of normally distributed variables, we used paired and one-tailed Student's $t$ tests with $a=0.05$ for statistical significance. Statistical analysis was performed with Prism 7.0 software (GraphPad Inc.).

\section{RESULTS}

\section{PAg-activated Vy9V $\delta 2 \mathrm{~T}$ cells are not sufficient for the} activation of autologous resting $\mathrm{V} \gamma \mathbf{V} \mathrm{V} \delta 2 \mathrm{~T}$ cells

The goal of this study was to determine how purified resting Vy9V82 T cells can be activated by soluble PAgs such as BrHPP. Classically, target cells such as tumor cells activate Vү9V $22 \mathrm{~T}$ cells through their butyrophilins, which are primarily activated by endogenous PAgs. However, even if the susceptibility of resting and activated Vy9V82 T cells to activation-induced cell death by TCR crosslinking is known [28], there is little research concerning the dialog between $\mathrm{V}_{\gamma} 9 \mathrm{~V} \delta 2 \mathrm{~T}$ cells under PAg stimulation in the absence of an accessory cell. Thus, we wondered whether $\mathrm{V} \gamma 9 \mathrm{~V} \delta 2$ $\mathrm{T}$ cells are also able to kill each other under PAg activation and whether the $\mathrm{V} Y \mathrm{~V} \delta 2$ killer needs PAg activation or if PAg sensing of the $V_{\gamma} 9 \mathrm{~V} \delta 2$ target cell alone was sufficient.

Purified resting $\gamma \delta T$ cells from the same donor were divided into two groups. One group was stained for the intracellular marker CMTMR, and the other was stained for the lipophilic membrane marker PKH67 (Fig. 1A). We considered CMTMR ${ }^{+}$

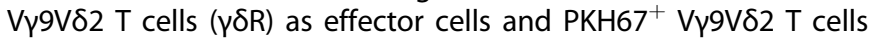
$(\gamma \delta G)$ as target cells. Daudi cells, from a cell line originating from a patient with Burkitt's lymphoma, were also used as a target cell control. $\gamma \delta$ T cells were prestimulated or not with $\operatorname{BrHPP}\left(\gamma \delta \mathrm{G}^{\mathrm{Br}}, \gamma \delta\right.$ $\left.R, \gamma \delta R^{B r}\right)$. We next wanted to determine whether $\gamma \delta$ T cells needed to be prestimulated with BrHPP to express CD107a. For that, we analyzed CD107a expression by $\gamma \delta R$ or $\gamma \delta R^{B r}$ cocultured with $\gamma \delta$ $\mathrm{G}^{\mathrm{Br}}$ by flow cytometry and showed that $\gamma \delta \mathrm{R}^{\mathrm{Br}}$ expressed CD107a after a coculture for $4 \mathrm{~h}$ but not $\gamma \delta \mathrm{R}$. In the same cocultures, $\gamma \delta$ $G^{B r}$ expressed CD107a in the two conditions: coculture with $\gamma \delta R$ or with $\gamma \delta R^{B r}$. The expression of CD107a by $V \gamma 9 V \delta 2 T$ cells in contact with autologous $\mathrm{V} \gamma 9 \mathrm{~V} \delta 2 \mathrm{~T}$ cells requires BrHPP prestimulation. However, this prestimulation with PAg is not necessary for Vy9V82 T cells cultivated with Daudi cells, which are known to express endogenous PAgs [29] (Fig. 1B, C). CD107a is expressed following the establishment of the immunological synapse (IS), during which membrane patches are exchanged between the two partners involved in this IS, a phenomenon called trogocytosis [30]. Acquisition of membrane PKH67 fluorescence by the $\mathrm{CMTMR}^{+}$group after $4 \mathrm{~h}$ of contact therefore reflects a stable IS, which is essential for the activation of lymphocytes [30]. We analyzed PKH67 fluorescence acquisition by $\gamma \delta R$ or $\gamma \delta R^{\mathrm{Br}}$ after 
A
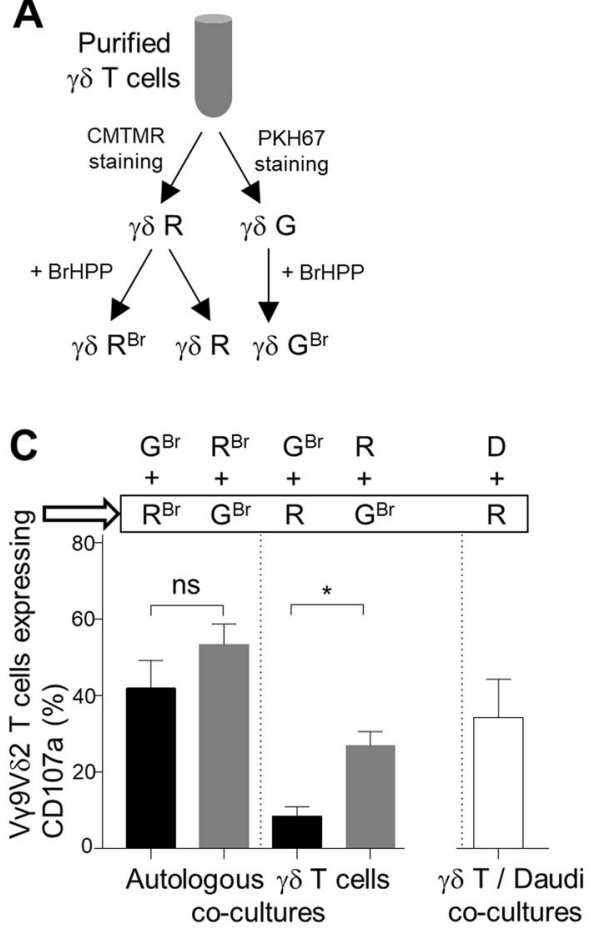

D $\quad 5 \mathrm{~min}$

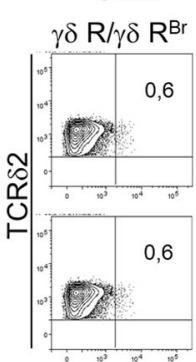

PKH-67
B

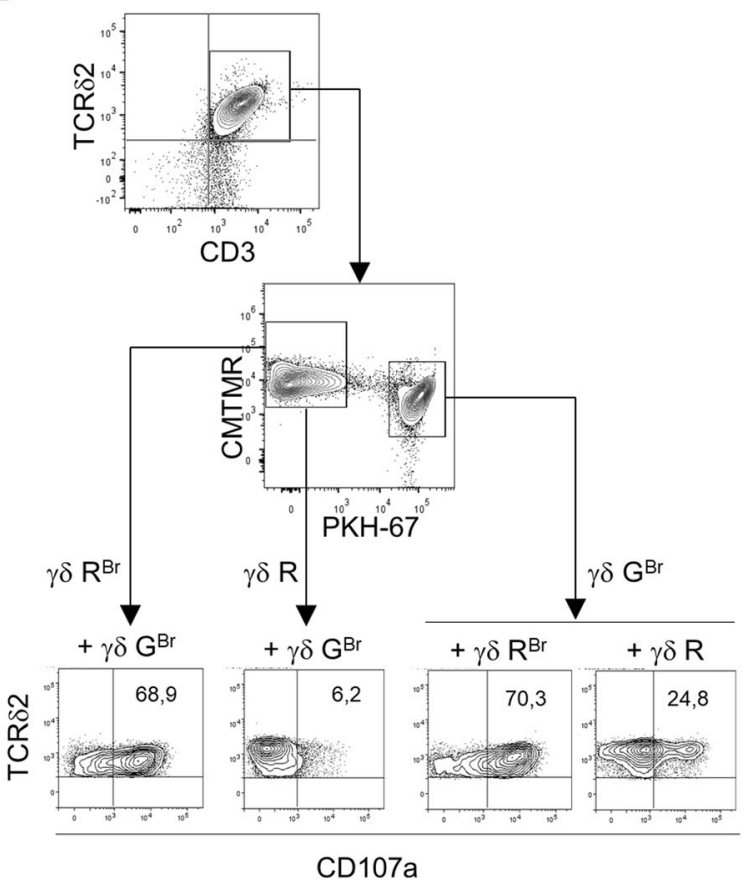

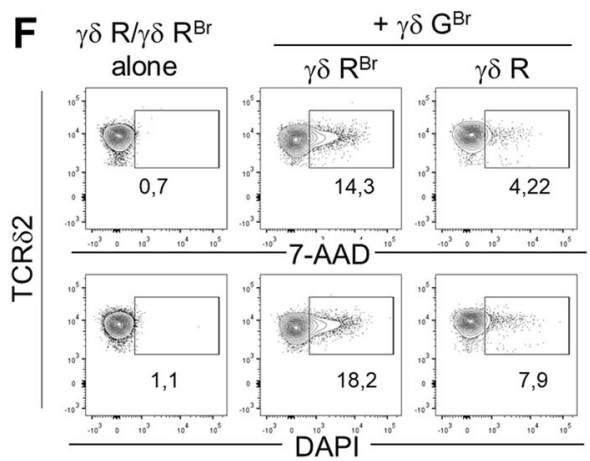
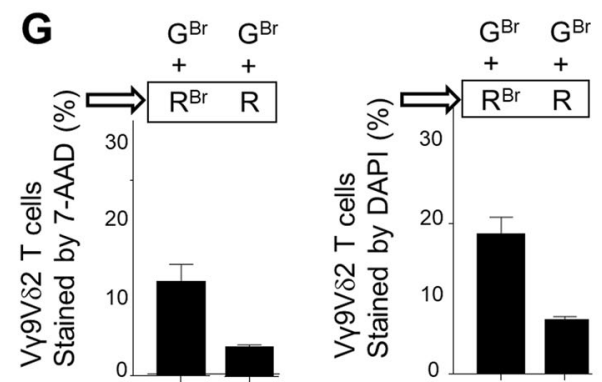

Autologous $\gamma \delta$ T cells co-cultures

Fig. 1 Autologous killing of purified $\mathrm{V} \gamma 9 \mathrm{~V} \delta 2 \mathrm{~T}$ cells requires PAg activation. A Flow chart of the $\mathrm{V} \gamma 9 \mathrm{~V} \delta 2 \mathrm{~T}$-cell preparation for coculture experiments ( $\gamma \delta \mathrm{R}$ : CMTMR ${ }^{+} \gamma \delta \mathrm{T}$ cells; $\gamma \delta \mathrm{R}^{\mathrm{Br}}$ : $\mathrm{CMTMR}^{+} \gamma \delta \mathrm{T}$ cells pretreated with BrHPP; $\gamma \delta \mathrm{G}^{\mathrm{Br}}$ : PKH67 ${ }^{+} \gamma \delta \mathrm{T}$ cells pretreated with BrHPP). B, C Flow cytometry analysis of CD107a expression by either $\gamma \delta \mathrm{R}^{\mathrm{Br}}$ or $\gamma \delta \mathrm{R}$ cocultured with $\gamma \delta \mathrm{G}^{\mathrm{Br}}$ or by $\gamma \delta \mathrm{G}^{\mathrm{Br}}$ cocultured with $\gamma \delta \mathrm{R}^{\mathrm{Br}}$ or $\gamma \delta \mathrm{R}$. B One representative experiment; $C$ Twelve independent experiments included CD107a expression by $\gamma \delta R$ cells cocultured with Daudi cells (D)). D, E Flow cytometry of PKH67 fluorescence acquisition by $\gamma \delta \mathrm{R}$ or $\gamma \delta \mathrm{R}^{\mathrm{Br}}$ after coculture for 5 min or $4 \mathrm{~h}$ with $\gamma \delta \mathrm{G}^{\mathrm{Br}}$ or with PKH67 $7^{+}$Daudi cells ( $D$ G). (D One representative experiment ( 5 min of coculture gave the same result for $\gamma \delta \mathrm{R}$ or $\gamma \delta \mathrm{R}^{\mathrm{Br}}$ ); E seven independent experiments). F, G Flow cytometry analysis of 7-AAD and DAPI staining of $\gamma \delta \mathrm{R}^{\mathrm{Br}}$ or $\gamma \delta$ R cells cocultured with $\gamma \delta \mathrm{G}^{\mathrm{Br}}$ cells. (F One representative experiment. G Three independent experiments). Asterisk $\left({ }^{*}\right)$ indicates $p<0.05$, Student's paired $t$ test; ns: not significant

5 min or $4 \mathrm{~h}$ in coculture with $\gamma \delta \mathrm{G}^{\mathrm{Br}} \cdot \gamma \delta \mathrm{R}^{\mathrm{Br}}$ cells acquired PKH67 fluorescence after $4 \mathrm{~h}$ of contact with $\gamma \delta \mathrm{G}^{\mathrm{Br}}$ but not $\gamma \delta \mathrm{R}$, although the same $\gamma \delta$ R cells were able to acquire PKH67 fluorescence after contact with $\mathrm{PKH}^{+} 7^{+}$Daudi cells (Fig. 1D, E). Thus, autologous trogocytosis between two $\mathrm{V} y 9 \mathrm{~V} \delta 2 \mathrm{~T}$ cells requires BrHPP prestimulation of the two partners.

To determine whether $\mathrm{V} Y 9 \mathrm{~V} \delta 2 \mathrm{~T}$ cells died following autologous trogocytosis, we quantified 7-AAD and DAPI staining of $\gamma \delta R$ or $\gamma \delta$ 
1864

$R^{B r}$ cocultured with $\gamma \delta G^{B r}$. We showed that only $\gamma \delta R^{B r}$ cells were stained with 7-AAD and DAPI when cocultured with $\gamma \delta G^{\mathrm{Br}}$ cells (Fig. 1F, G). Therefore, a Vy9V $\delta 2 \mathrm{~T}$ cell needs to be stimulated by PAgs to kill another $\mathrm{V} \gamma 9 \mathrm{~V} \delta 2 \mathrm{~T}$ cell only if this cell is also activated by PAgs.

\section{Vy9Vס2 T cells can self-activate through BrHPP in a TCR- and butyrophilin-dependent manner}

The above results led us to ask how purified $\gamma \delta$ T lymphocytes can be activated by exogenous PAgs without any target cell and without cell contact. Thus, we monitored the calcium flux of individual $\mathrm{V} \gamma 9 \mathrm{~V} \delta 2 \mathrm{~T}$ cells by video microscopy under stimulation with exogenous PAgs (BrHPP, CHDMAP, or IPP) or with ionomycin, a calcium ionophore, as a positive control. Fresh $\gamma \delta T$ cells sorted from blood samples of healthy donors were loaded with the calcium probe Fluo-8 AM-tagged and then coated on a microslide at a limited cell concentration to avoid cell contact. The stimulator was added with care to the well under the microscope $2 \mathrm{~min}$ after starting the video to detect the green fluorescence of the calcium flux (Fig. 2A). Stimulation with ionomycin led to a rapid increase in Fluo-8 AM fluorescence followed by stabilization (Fig. 2B). The Fluo-8 AM profile obtained with BrHPP stimulation was different, with several peaks of calcium flux in the same isolated $\mathrm{V} y 9 \mathrm{~V} \delta 2 \mathrm{~T}$ cell (Fig. 2C, Supplementary Fig. 1 for the video). These profiles were reproduced for several isolated $\mathrm{V} \gamma 9 \mathrm{~V} \delta 2 \mathrm{~T}$ cells from different donors by measuring the ratio (Fluo-8 AM intensity mean/cell area) before and during stimulation with ionomycin or BrHPP (Fig. 2D). A significant increase in fluorescence in isolated $\gamma \delta$ T cells was observed with ionomycin activation and BrHPP stimulation. This self-activation was shown with other PAgs, such as cHDMAP and IPP (Supplementary Fig. 2). The expression of IFN- $\gamma$, CD107a and CD69 measured by flow cytometry confirmed that $\mathrm{V} Y 9 \mathrm{~V} \delta 2 \mathrm{~T}$ cells can be activated by the exogenous PAgs BrHPP, CHDMAPP and IPP without a target or accessory cell. The same results were reproduced with antiCD3/CD28 beads as a positive control (Supplementary Fig. 3). Interestingly, $V_{Y} 9 \mathrm{~V} \delta 2 \mathrm{~T}$ cells were not activated by an ABP such as zoledronate after incubation for $4 \mathrm{~h}$, overnight or 4 days, whereas Vy9V $\delta 2 \mathrm{~T}$ cells could be amplified in cultures of PBMCs as with BrHPP in the presence of IL2 and zoledronate (Supplementary Fig. 4).

All these results show that $\mathrm{V} \gamma 9 \mathrm{~V} \delta 2 \mathrm{~T}$ cells can self-activate with exogenous PAgs without cell contact.

Next, we asked whether this PAg self-activation involved the same actors depicted for $\mathrm{V} 9 \mathrm{~V} \delta 2$ T-cell activation in the context of contact with tumor cells. First, we checked that resting $V_{Y} 9 \mathrm{~V} \delta 2 \mathrm{~T}$ cells expressed BTN2A1 and BTN3A1 on their cell surface (Supplementary Fig. $5 A$ ) and that fresh $V y 9 V \delta 2$ T cells could be activated by the BTN3A1 agonist (Supplementary Fig. 5B). Then, we analyzed the calcium flux in a single cell in the presence of blocking antibodies by video microscopy during BrHPP stimulation. Blocking antibodies against TCR and the two butyrophilins succeeded in decreasing calcium flux when added to cells stimulated by BrHPP (Fig. 2E, F and Supplementary Fig. 6 for the videos). Furthermore, the expression of IFN- $\gamma$, CD107a, and CD69 was measured by flow cytometry in purified resting $\mathrm{V}_{\gamma} 9 \mathrm{~V} \delta 2 \mathrm{~T}$ cells stimulated with BrHPP in the presence or absence of blocking antibodies against TCR, BTN3A1, or BTN2A1. A clear decrease in the expression of the three markers was obtained for $\mathrm{V}_{\gamma} 9 \mathrm{~V} \delta 2$ T cells stimulated by BrHPP in the presence of each blocking antibody but not for $\mathrm{V}_{Y} 9 \mathrm{~V} \delta 2 \mathrm{~T}$ cells stimulated with anti-CD3/ CD28 beads (Supplementary Fig. 5C, D).

Thus, we showed that all the actors involved in the PAg-induced activation of $\mathrm{V} Y \mathrm{~V} \delta 2 \mathrm{~T}$ cells in a cell contact context with tumor cells are also engaged in PAg self-activation.

\section{Preexisting clustering of $Y 9 T C R$ with BTN2A1 and BTN3A1 in resting Vy9Vס2 $\mathrm{T}$ cells}

The next step was to understand the configuration of the involvement of $\gamma 9 T C R, B T N 2 A 1$ and BTN3A1 at the surface of V $ү 9 \mathrm{~V} \delta 2 \mathrm{~T}$ cells under BrHPP stimulation. To depict in detail $\mathrm{V} \gamma 9 \mathrm{~V} \delta 2$ T-cell self-activation, we performed immunofluorescence staining of these three molecules on resting purified $\mathrm{V} \gamma 9 \mathrm{~V} \delta 2 \mathrm{~T}$ cells during activation with BrHPP ( $200 \mathrm{nM}$ for 3,10 , or $45 \mathrm{~min}$ ) or ionomycin (10 $\mu \mathrm{M}$ for $10 \mathrm{~min})$ (Fig. 3A). As expected, we showed that $\mathrm{Y} 9 \mathrm{TCR}$ expression (green fluorescence) was evenly distributed on the surface of fresh purified resting VY9V82 T cells. Y9TCR, BTN2A1, and BTN3A1 were colocalized in several parts of the membrane before or after BrHPP stimulation, as shown in the profiles in the right panel of Fig. 3A. However, the colocalizations between the three structures were not equivalent. $y 9 T C R$ was more colocalized with BTN2A1 than with BTN3A1, with Manders' coefficients of 0.86 vs. 0.56 (Fig. $3 \mathrm{~B}$ ). Then, we asked whether these colocalizations could be modulated upon BrHPP or ionomycin stimulation. The coefficient of colocalization of $Y 9 T C R$ with BTN3A1 or BTN2A1 was not significantly modified, nor was that of BTN3A1/BTN2A1 colocalization (Fig. 3B).

To analyze the dynamics of these membrane proteins during stimulation with exogenous BrHPP, we quantified their fluorescence intensity according to the duration of the stimulation (Fig. 3C). The intensity of fluorescence was normalized to that of the untreated cells. A fluctuation of the fluorescence for $y 9 T C R$ was shown with a quick decrease after 3 min of stimulation with BrHPP and then an increase after 10 min to again decrease after a longer stimulation time (45 min). However, the fluorescence for Y9TCR observed after 10 min of stimulation with ionomycin was not modified compared to the unstimulated condition. Similar to Y9TCR fluorescence, BTN2A1 fluorescence decreased rapidly after 3 min of BrHPP stimulation to return to a similar intensity to the unstimulated control after $10 \mathrm{~min}$. In contrast, the mean intensity of fluorescence for BTN3A1 increased but not in the first minutes, only from $10 \mathrm{~min}$, and remained stable, while ionomycin stimulation did not change the fluorescence of BTN3A1.

Thus, all these results show that freshly purified $\mathrm{V} \gamma 9 \mathrm{~V} \delta 2 \mathrm{~T}$ cells transitorily modulate their early expression of BTN2A1 and $\gamma 9 T C R$ and later BTN3A1 expression under BrHPP activation.

Finally, we wondered whether exogenous BrHPP needs to enter Vy9V82 T cells to activate them through the membrane cluster Y9TCR/BTN2A1/BTN3A1. As the Massimo Massaia group has shown that the $A B C A 1$ transporter could be involved in IPP trafficking across the membrane [24], we investigated whether this transporter could be used for the transport of exogenous BrHPP inside $\mathrm{V} y 9 \mathrm{~V} \delta 2 \mathrm{~T}$ cells. Using probucol, a specific inhibitor of $A B C A 1$ that is not toxic to $\mathrm{V} \gamma 9 \mathrm{~V} \delta 2 \mathrm{~T}$ cells (Supplementary Fig. 7), we showed a total abrogation of calcium flux in $\mathrm{V} y 9 \mathrm{~V} \delta 2 \mathrm{~T}$ cells activated by BrHPP in the presence of probucol (Fig. 4A), with a significant decrease in Fluo-8 AM intensity in Vy9V $\delta 2$ T cells treated with probucol before BrHPP stimulation (Fig. 4B). The involvement of ABCA1 in BrHPP stimulation was confirmed by a significant decrease in the expression of IFN- $\gamma$, CD107a and CD69 by purified resting $\mathrm{V} \gamma 9 \mathrm{~V} \delta 2 \mathrm{~T}$ cells stimulated by BrHPP, while stimulation with anti-CD3/CD28 beads was not affected (Fig. 4C (representative experiment) and Fig. 4D (pool of independent experiments)).

These results indicate that $A B C A 1$ could be used by exogenous BrHPP to penetrate Vy9V $\delta 2 \mathrm{~T}$ cells before self-activation.

\section{DISCUSSION}

Recent years have seen renewed interest in $\mathrm{V} \gamma 9 \mathrm{~V} \delta 2$ T-cell therapies and new strategies using Vy $9 \mathrm{~V} \delta 2 \mathrm{~T}$ cells (reviewed in [9]). Despite increased knowledge of many components involved in the Vy9V $\delta 2$ T-cell activation process, the mechanism is still 


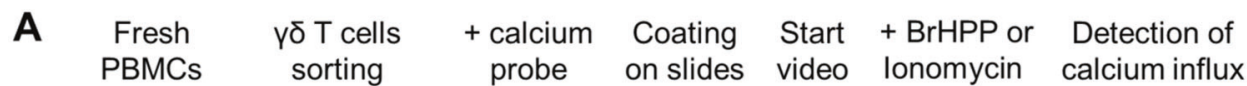

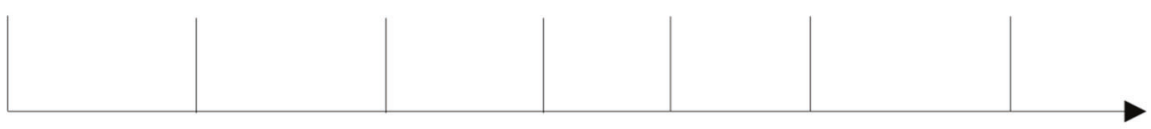

B

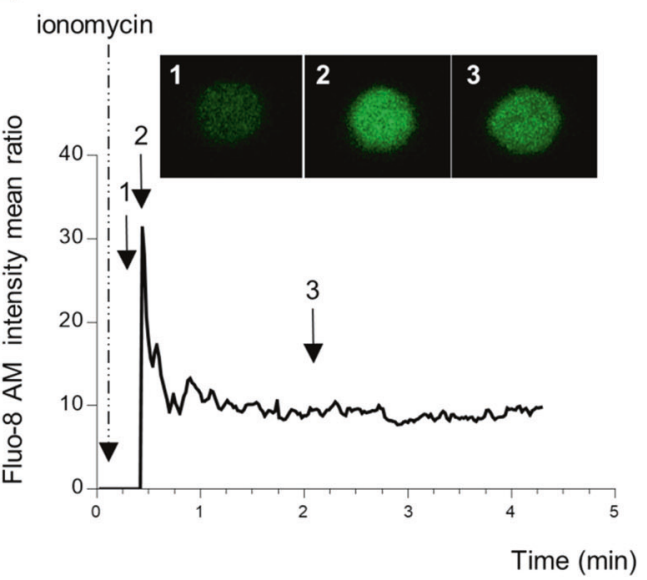

D

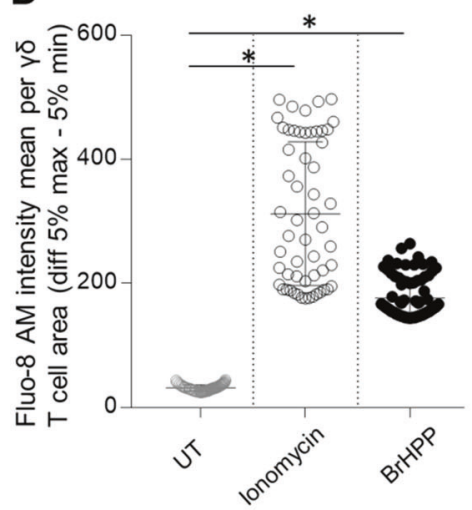

F

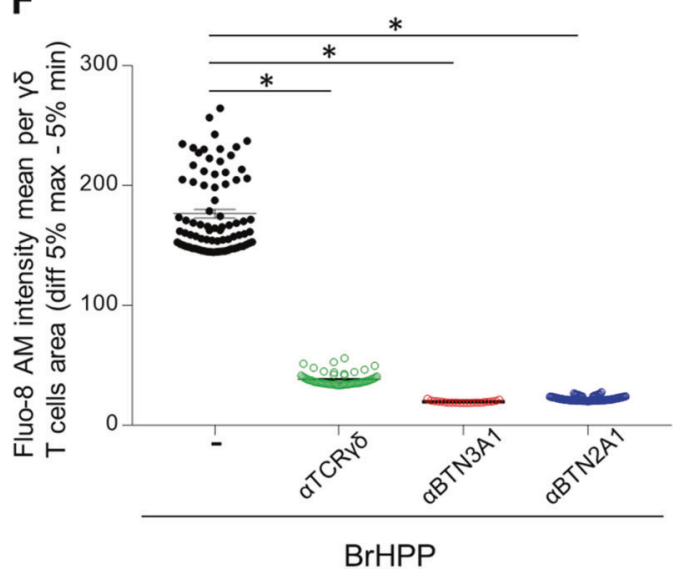

C

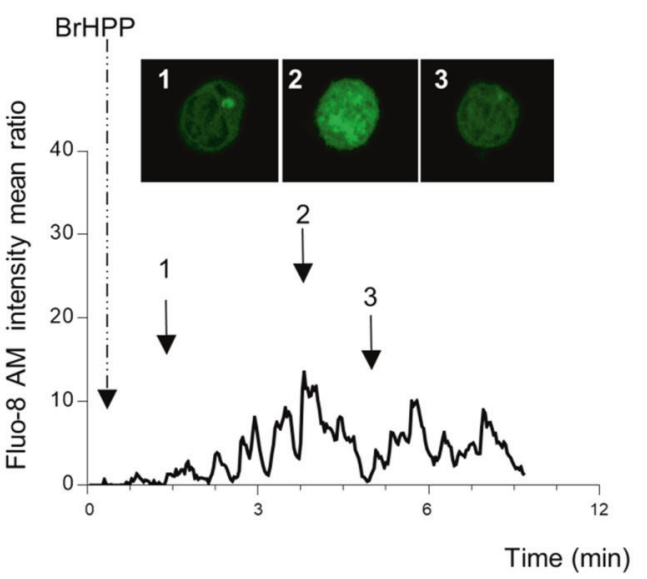

E

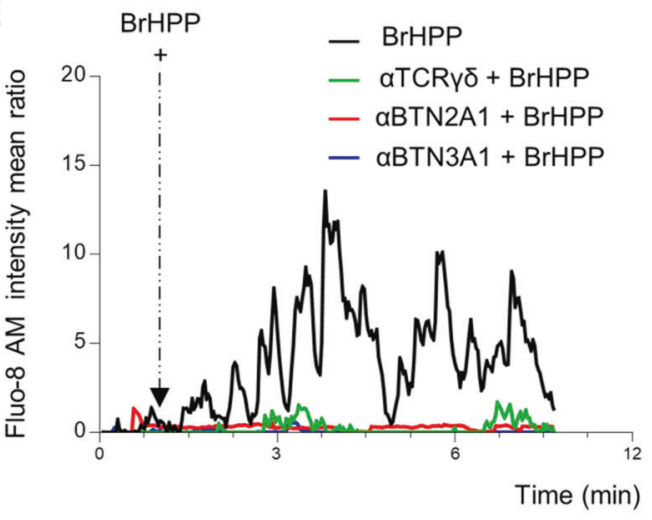

Fig. 2 Self-activation of resting purified $\mathrm{V} \gamma 9 \mathrm{~V} \delta 2 \mathrm{~T}$ cells by exogenous BrHPP is dependent on TCR, BTN3A1, and BTN2A1. A Sequence of actions for calcium flux detection by video in an individual $\mathrm{V} \gamma 9 \mathrm{~V} \delta 2 \mathrm{~T}$ cell. B-E Time lapse of the Fluo-8 AM intensity representing the calcium flux in one $\mathrm{V} \gamma 9 \mathrm{~V} \delta 2 \mathrm{~T}$-cell stimulated by ionomycin (B) or exogenous BrHPP (C). Three images were extracted from the time lapses at three different time points of the stimulation. D Mean Fluo-8 AM intensity per $\gamma \delta$ T cell area (difference $5 \%$ max-5\% min). F Time lapse of the Fluo-8 AM intensity representing the calcium flux in one $\mathrm{V} \gamma 9 \mathrm{~V} \delta 2 \mathrm{~T}$-cell stimulated by BrHPP in the presence or absence of blocking antibodies against $\gamma$ 9TCR, BTN3A1. or BTN2A1. Asterisk $\left(^{*}\right)$ indicates $p<0.05$, Student's paired $t$ test; ns not significant 
A
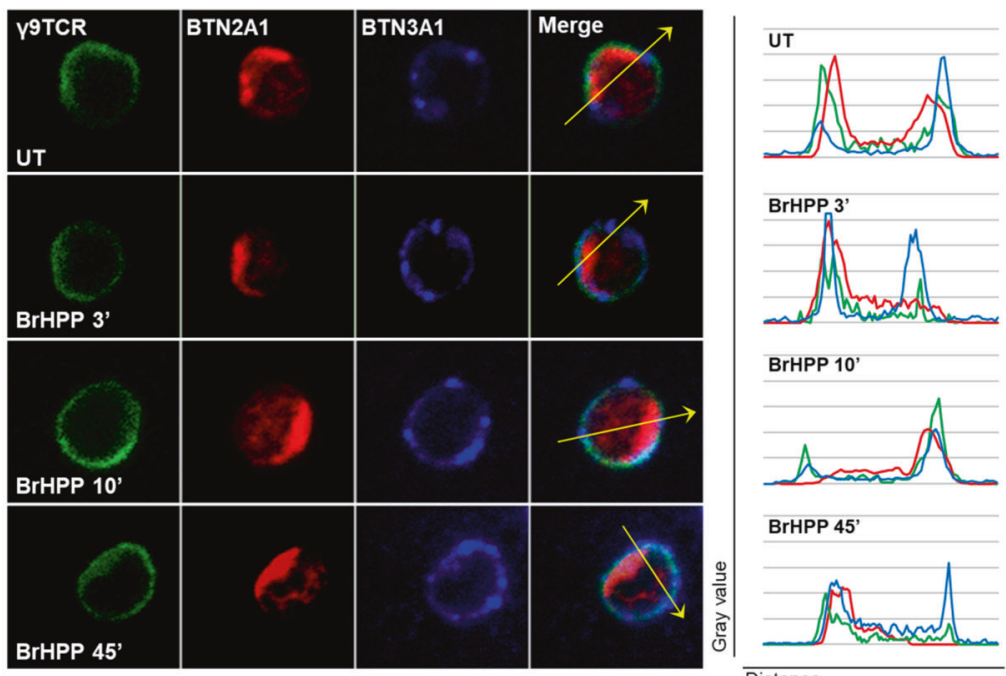

BrHPP 10'

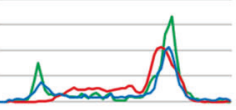

BrHPP 45'
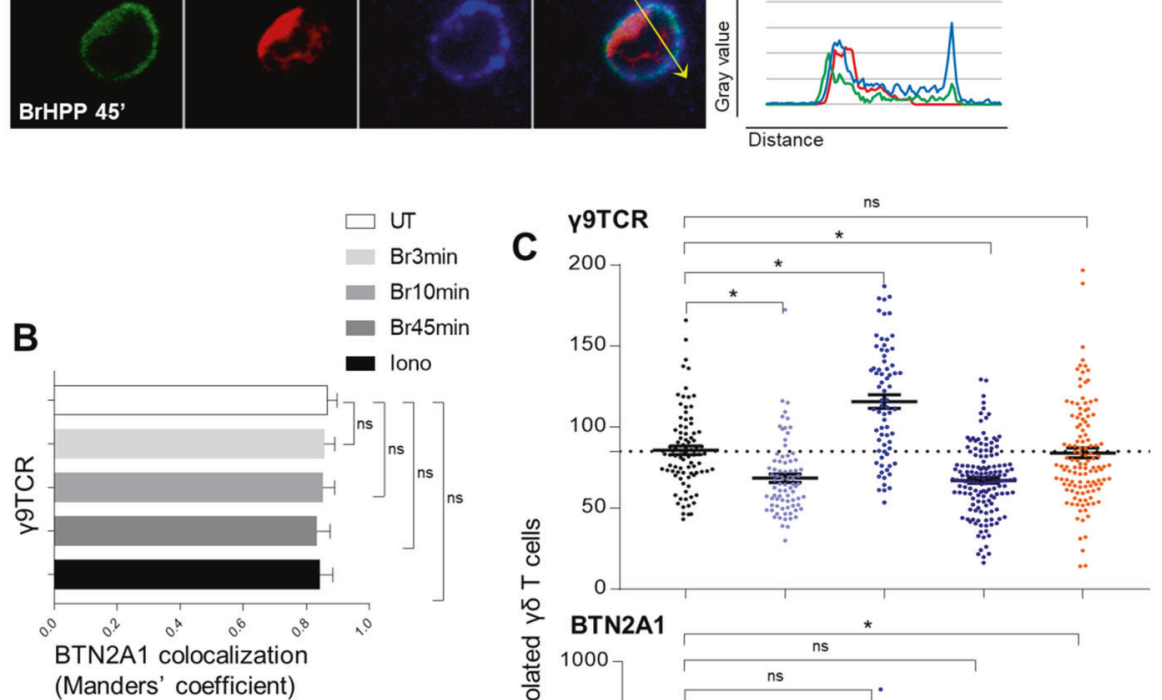

(Manders' coefficient)
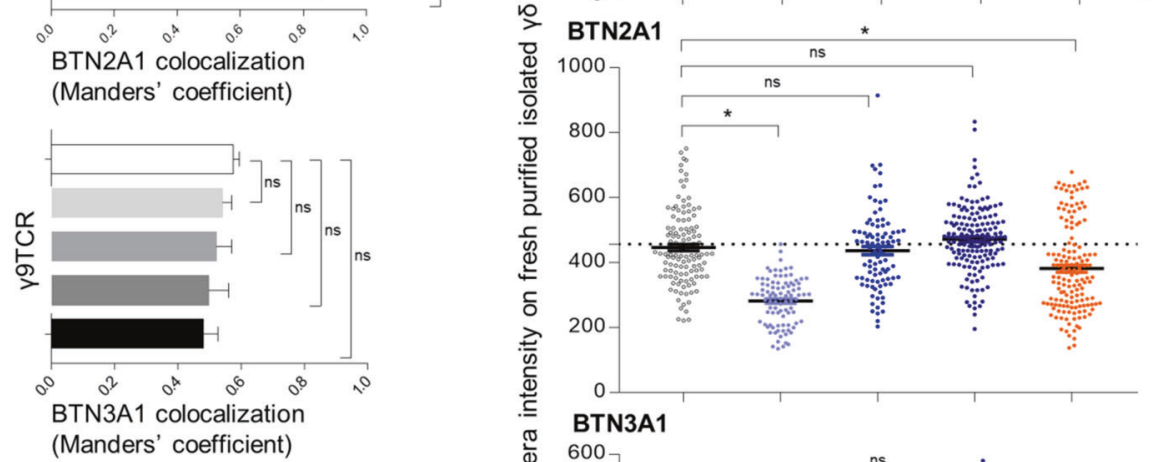

(Manders' coefficient)

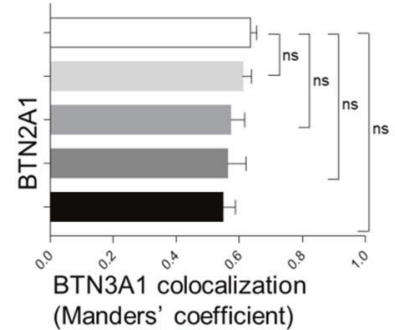

BTN3A1

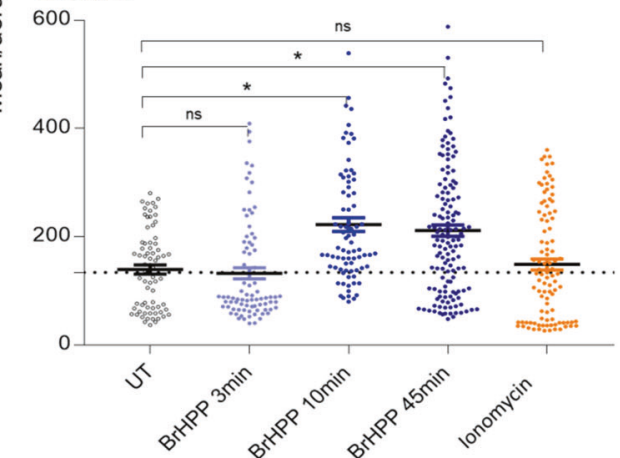

Fig. 3 Preexisting clusters of $\gamma 9 T C R, B T N 2 A 1$ and BTN3A1 at the surface of resting $\mathrm{V} \gamma 9 \mathrm{~V} \delta 2 \mathrm{~T}$ cells and their modulation during BrHPP stimulation. A Immunofluorescence of $\gamma 9 T C R, B T N 2 A 1$ and BTN3A1 on freshly purified isolated $\mathrm{V} \gamma 9 \mathrm{~V} \delta 2 \mathrm{~T}$ cells during BrHPP stimulation (representative images, $\gamma 9 T C R$ : green fluorescence, BTN2A1: red fluorescence and BTN3A1: blue fluorescence and the merge) and colocalization profiles for each condition corresponding to the arrow). B Comparison of the colocalization of $\gamma 9 T C R$, BTN2A1 and BTN3A1 on freshly purified isolated $\mathrm{V} \gamma 9 \mathrm{~V} \delta 2 \mathrm{~T}$ cells during BrHPP or ionomycin stimulation quantified by Manders' coefficient in ImageJ software. C Mean/ area intensity of $\gamma 9 \mathrm{TCR}, \mathrm{BTN} 2 \mathrm{~A} 1$, and BTN3A1 on freshly purified isolated $\mathrm{V} \gamma 9 \mathrm{~V} \delta 2 \mathrm{~T}$ cells during BrHPP or ionomycin stimulation. Asterisk $\left({ }^{*}\right)$ indicates $p<0.05$, Student's paired $t$ test; ns not significant 
A

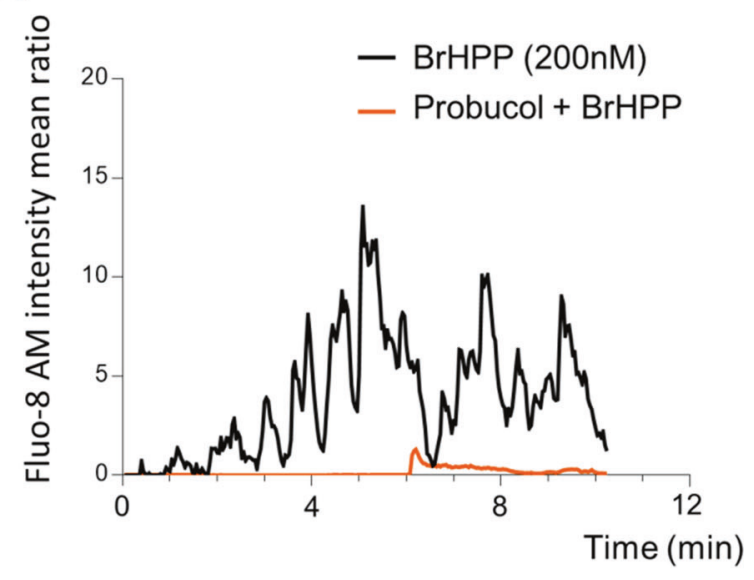

B

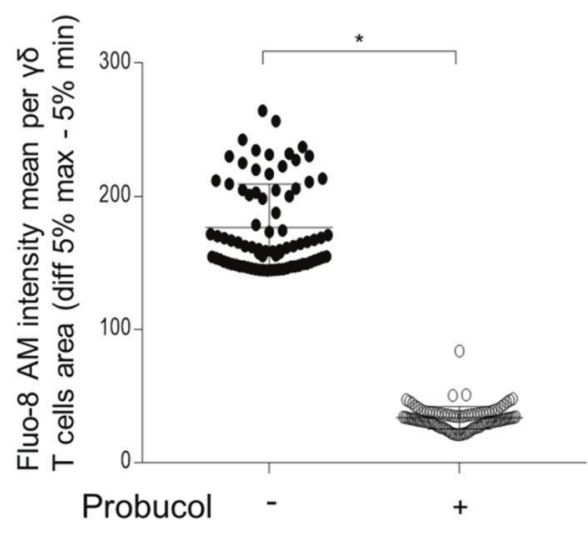

C

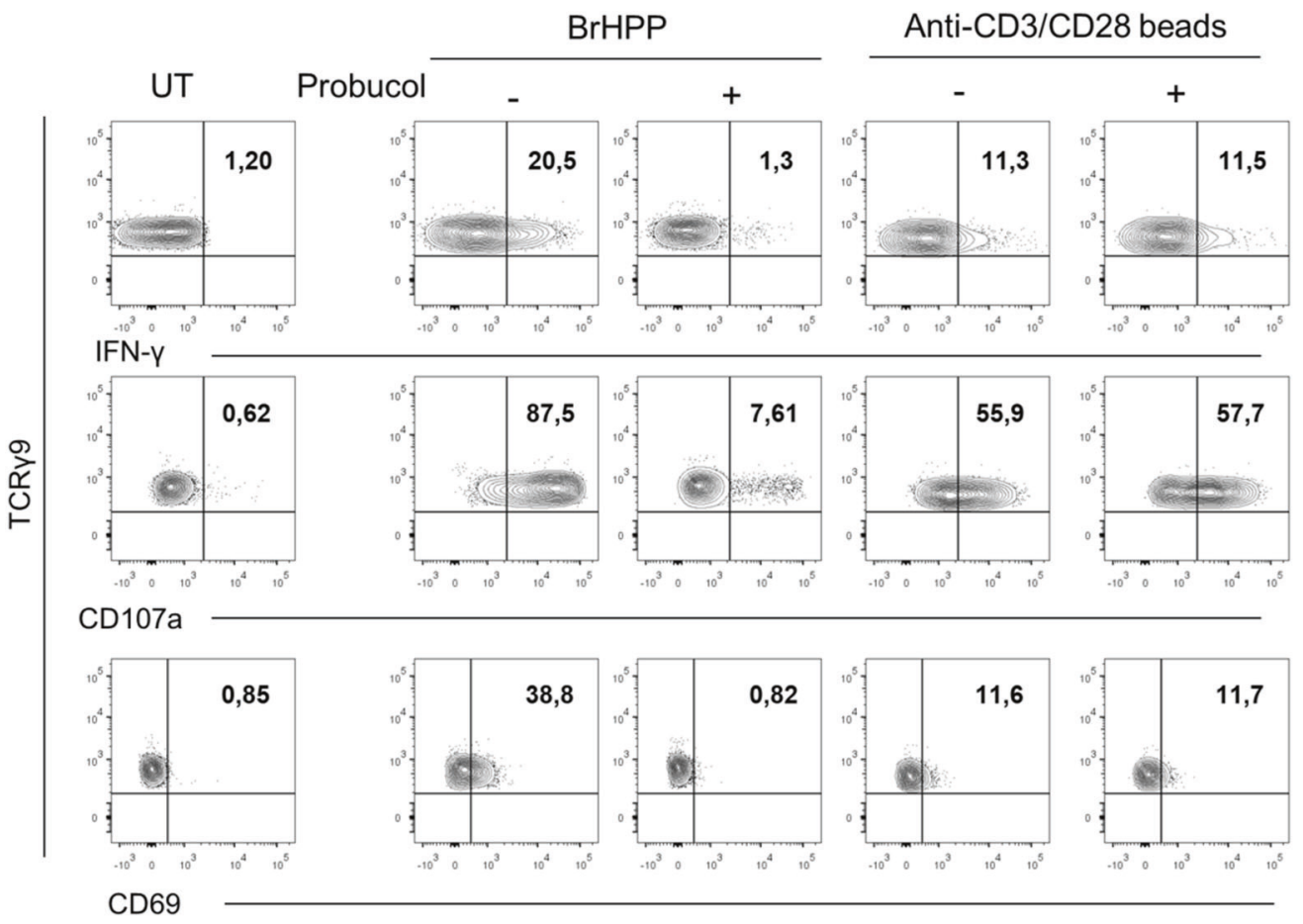

D
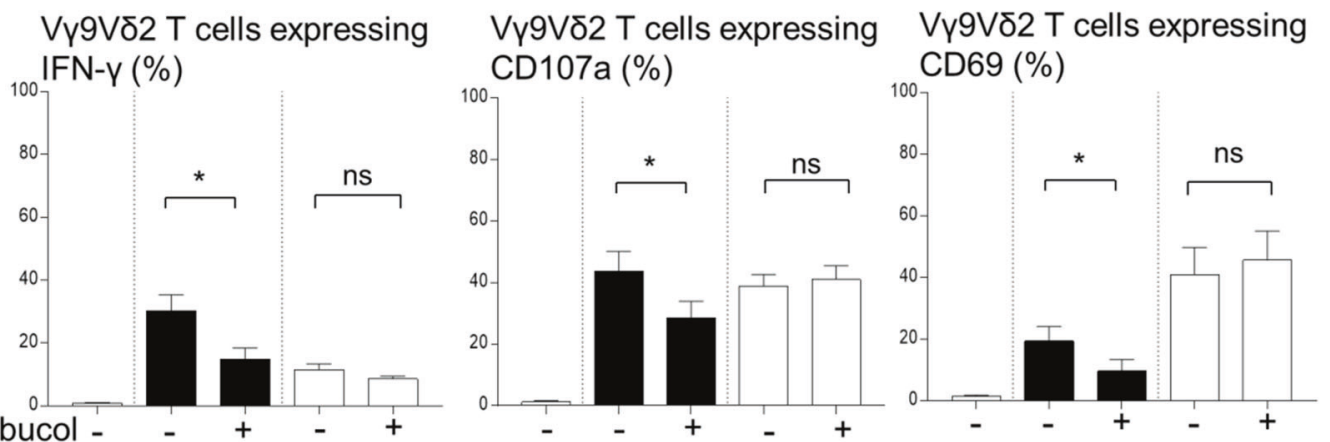

Fig. 4 Inhibition of ABCA-1 by probucol impairs BrHPP self-activation of resting purified V $\gamma 9 \mathrm{~V} \delta 2 \mathrm{~T}$ cells. A Time lapse of the Fluo-8 AM intensity representing the calcium flux in one $\mathrm{V} \gamma 9 \mathrm{~V} \delta 2$ T-cell stimulated by BrHPP and previously treated with Probucol (10 $\mu \mathrm{M}$, overnight). B Mean Fluo-8 AM intensity per $\gamma \delta$ T-cell area (difference $5 \%$ max $-5 \%$ min). C, D Flow cytometry analysis of the expression of CD69 and CD107a and IFN- $\gamma$ production by fresh purified V $\gamma 9 \mathrm{~V} \delta 2 \mathrm{~T}$ cells activated by BrHPP or anti-CD3/CD28 beads previously treated with Probucol $(10 \mu \mathrm{M}$, overnight). (C A representative experiment; D Four independent experiments; black: V $\gamma 9 \mathrm{~V} \delta 2 \mathrm{~T}$ cells activated by BrHPP; white: V $\gamma 9 \mathrm{~V} \delta 2$ T cells activated by anti-CD3/CD28 beads). Asterisk $\left(^{*}\right)$ indicates $p<0.05$, Student's paired $t$ test; ns not significant 
elusive, and it must be known fully to understand the potential reasons for the failure of therapeutic strategies involving $\mathrm{V}_{\gamma} 9 \mathrm{~V} \delta 2$ $T$ cells [31]. Among these components, butyrophilins, such as BTN3A1 and, more recently, BTN2A1, were shown to be key costimulatory molecules during $\mathrm{V} \gamma 9 \mathrm{~V} \delta 2 \mathrm{~T}$-cell activation by $\mathrm{PAg}$ sensing targets $[18,20,21]$. Several studies have demonstrated that BTN3A1 acts as a PAg sensor thanks to the interaction of its intracellular domain B30.2 with PAg [31-33] and to the cooperation of three BTN3 isoforms necessary for complete activation [19]. Although BTN3A1 was not shown to be directly linked to Y9TCR during PAg activation with a target cell, the interaction between BTN2A1 and TCR was shown to be essential in this process, as was the interaction between BTN2A1 and BTN3A1 [20, 21]. The interaction of BTN3A1 and Y9TCR is still an open question, as well as the possibility that BTN3A1 might serve as a chaperone molecule that brings another ligand to the cell surface, also not excluding the direct binding of BTN3A1 with Y9TCR [18].

All these discoveries were found in $\mathrm{V} y 9 \mathrm{~V} \delta 2 \mathrm{~T}$-cell activation in the presence of an accessory or a target cell, i.e., tumor cells naturally or pharmacologically overexpressing PAg or that were pretreated with exogenous PAg. Some early studies reported that VY9V $\delta 2$ T cells could be activated directly by nonpeptidic mycobacterial ligands or by synthetic BrHPP, but there was no evidence of direct interaction of these PAgs and the TCR or other membrane molecules on V $\gamma 9 \mathrm{~V} \delta 2 \mathrm{~T}$ cells $[34,35]$. Based on these studies and others showing proliferation and production of IFN- $\gamma$ by resting pure $\mathrm{V} Y 9 \mathrm{~V} \delta 2 \mathrm{~T}$ cells or $\delta 2 \mathrm{TCR} \mathrm{T}$-cell clones treated with exogenous PAg and IL-2 [36-38], it seemed important to depict the mechanism of this direct activation.

In this study, we confirmed that $\mathrm{V} \gamma 9 \mathrm{~V} \delta 2 \mathrm{~T}$ cells could be directly activated by exogenous PAgs, i.e., BrHPP. We detected calcium flux in isolated pure resting cells very quickly after contact with exogenous PAg. The increase in intracellular calcium concentration was clearly shown to reflect TCR engagement and T-cell activation. Indeed, this calcium modulation is necessary for cytoskeletal remodeling during TCR signaling and the establishment of T-cell responses (reviewed in ref. [39]). Flow cytometry detection of the expression of CD107a, IFN- $\gamma$ and CD69 and the fratricide of Vy9V $22 \mathrm{~T}$ cells following BrHPP stimulation was consistent with self-activation. This phenomenon was also confirmed by the impossibility of $\mathrm{V}_{\gamma} \mathrm{V} \mathrm{V} \delta 2 \mathrm{~T}$ cells to play the role of presenting cells for autologous resting $\mathrm{V}_{\gamma} 9 \mathrm{~V} \delta 2 \mathrm{~T}$ cells. Furthermore, we showed that a $\mathrm{V}_{\gamma} 9 \mathrm{~V} \delta 2 \mathrm{~T}$ cell needs to be stimulated by PAg to kill another $\mathrm{V} \gamma 9 \mathrm{~V} \delta 2 \mathrm{~T}$ cell after trogocytosis. CD107a expression and dead cells were not observed for Vy9V $\delta 2$ $T$ cells not prestimulated by exogenous PAg in coculture with Vү9V $\delta 2$ T cells prestimulated by exogenous PAg (Fig. 1). A V $ү 9 \mathrm{~V} \delta 2$ $T$ cell, therefore, cannot activate the TCR of another $\mathrm{V} Y 9 \mathrm{~V} \delta 2 \mathrm{~T}$ cell by its PAg-sensed butyrophilins.

Interestingly, we did not detect any increase in intracellular calcium concentration or expression of CD107a, IFN- $\gamma$ and CD69 in Vy9V82 T cells treated with zoledronate for 4,18 , or 4 days. Aminobisphosphonate (ABP) treatments have been shown to activate $\mathrm{V} y 9 \mathrm{~V} \delta 2 \mathrm{~T}$ cells but always in the context of contact between Vy9V $\delta 2 \mathrm{~T}$ cells and accessory cells such as macrophages or dendritic cells in PBMCs or tumor cells. Indeed, accessory cells are generally pretreated with an $A B P$, such as zoledronate, to activate the production of endogenous PAg that can bind to the intracellular part of BTN [40-45]. The mechanism of action of zoledronate on $\mathrm{V} 9 \mathrm{~V} \delta 2 \mathrm{~T}$ cells remains unsolved: are $\mathrm{V} \gamma 9 \mathrm{~V} \delta 2$ T cells unable to accumulate endogenous PAg, or are they unable to be activated by endogenous PAg?

PAg self-activation raised the question of the factors involved in this process. We showed here that Y9TCR, BTN3A1 and BTN2A1 were involved in BrHPP self-activation, as the application of blocking antibodies clearly decreased the calcium flux and expression of CD107a, IFN- $\gamma$, and CD69 on Vy9V82 T cells. Vy9V82 T-cell activation by anti-CD3/CD28 beads was, however, not impacted by blocking antibodies, therefore supporting the specific contribution of the three partners to BrHPP self-activation. Vy9V82 T cells are consequently able to respond to exogenous PAg through $Y 9 T C R, B T N 3 A 1$ and BTN2A1, which are expressed at their surface. The modulation of the membrane expression of each of these membrane proteins also supports the PAg self-activation of $\mathrm{V} \mathrm{V} \mathrm{V} \delta 2 \mathrm{~T}$ cells. We have indeed shown that $\mathrm{Y} 9 \mathrm{TCR}$ can be very quickly downregulated, similar to BTN2A1, while BTN3A1 was upregulated later. This is consistent with previous results showing the downregulation of the TCR following contact with PAgsensing targets $[46,47]$ and the modulation of the expression of butyrophilins [19]. Modifications of the conformation of the butyrophilins in the presence of PAgs could also favor a weaker accessibility of antibodies to detect these proteins at the membrane surface [20, 21]. Moreover, very recent work has suggested that $\gamma 9 T C R$ directly interacts with BTN2A1 at the target surface and not with BTN3A1, while the latter was shown to interact with BTN2A1 [20]. This could be accompanied by an upregulation in expression or a change in conformation later than for BTN2A1, as shown in Fig. 3C. The very rapid modulation of Y9TCR and BTN2A1 membrane expression in the first minutes after stimulation reflects the rapid modification of calcium flux observed under PAg stimulation. TCR engagement induces the modulation of calcium flux, which is mandatory for cytoskeletal remodeling, allowing calcium signaling as well as NKG2D costimulation, which leads to T-cell responses [39, 48]. Early modulation of $\mathrm{Y} 9 \mathrm{TCR}$ and BTN2A1 expression and modulation of BTN3A1 are thus consistent with all of these observations.

Furthermore, the preexisting colocalization of $Y 9 T C R, B T N 3 A 1$, and BTN2A1, which form several clusters at the surface of $V_{\gamma} 9 \mathrm{~V} \delta 2$ $\mathrm{T}$ cells, was not modified in response to PAg treatment, which is consistent with the successive activation of isolated $\mathrm{V} y 9 \mathrm{~V} \delta 2 \mathrm{~T}$ cells reflected by an irregular calcium flux profile compared to the uniform profile under ionomycin stimulation.

The sequence proposed by different studies, i.e., sensing of the intracellular domain of BTN3A1, conformational modification of BTN3A1, interaction with BTN2A1 and then interaction of BTN2A1 with $\gamma 9 T C R[21,44]$ could therefore be applied during PAg selfactivation on a single $\gamma \delta T$ cell. However, to date, nothing has been shown regarding the possible interaction of BrHPP and the B30.2 intracellular part of BTN3A1, as has been demonstrated for other PAgs, such as (E)-1-hydroxy-2-methyl-but-2-enyl 4diphosphate (HMBPP) [32]. If BrHPP were able to interact with the B30.2 part of BTN3A1, the question is how this molecule can penetrate inside $\mathrm{V} Y 9 \mathrm{~V} \delta 2 \mathrm{~T}$ cells. ABCA1 was shown to physically associate with BTN3A1 on zoledronate-treated dendritic cells as a function of extracellular IPP release [24]. ABCA1, as another (ATP)binding cassette $(A B C)$ transporter, is a ubiquitous molecule expressed at the plasma membrane with bifunctional action, hydrolyzing ATP to ADP, and inorganic phosphate and exporting molecules such as cholesterol or calpains $[49,50]$. ABCA1 can bind the extracellular domain of apolipoprotein A-I (apoA-I), which is required for the assembly of nascent high-density lipoprotein (HDL) mediating cholesterol transport [51]. Moreover, apoA-1 can bind F1-ATPase, which was shown to be an important molecule involved in $V_{Y} 9 \mathrm{~V} \delta 2$ T-cell activation [52, 53]. These $A B C$ transporters, which can also form complexes with other proteins to act as channels for export and import [49], can be inhibited by probucol. Indeed, several studies have shown that probucol was able to block cholesterol efflux, especially in smooth muscle cells, in the same way as ABCA1-KO of these cells [54, 55]. However, probucol was also shown to block ion channels, especially potassium channels, in cardiac cells $[56,57]$. Using probucol, we showed in our study a clear decrease in Vy9V $\delta 2$ T-cell selfactivation by exogenous BrHPP, with a total inhibition of calcium flux and CD107a and IFN- $\gamma$ expression, while stimulation with antiCD3/CD28 beads was not impaired by pretreatment with probucol. These results strongly suggested that exogenous BrHPP 
can penetrate inside $\mathrm{V} y 9 \mathrm{~V} \delta 2 \mathrm{~T}$ cells through transporters inhibited by probucol. This can be extended to the BrHPP sensing of tumor cells thanks to the penetration of BrHPP through the same transporters, including ABCA1. Indeed, pretreatment with BrHPP in some lung cancer cell lines induced activation of $\mathrm{V} \gamma 9 \mathrm{~V} \delta 2$ T cells [58].

Altogether, these results provide the first evidence that selfactivation of pure resting $\mathrm{V} Y \mathrm{~V} \mathrm{~V} \delta 2 \mathrm{~T}$ cells from blood by exogenous PAg involves the $Y 9 T C R, B T N 3 A 1$ and BTN2A1 organized in clusters at the plasma membrane. Some transporters associated with BTN3A1, such as $A B C A 1$, could be considered critical for the entrance of PAgs into Vy9V $\delta 2$ T cells before activation of the B30.2 domains of BTN3A1.

Even though $\mathrm{V} Y 9 \mathrm{~V} \delta 2 \mathrm{~T}$ cells are now widely considered highly potent antitumor effectors, $\gamma \delta \mathrm{T}$ cell-based therapies with exogenous PAgs are lacking in efficacy. Self-activation with exogenous PAgs such as BrHPP leading to the autologous killing of $\mathrm{V} \gamma 9 \mathrm{~V} \delta 2 \mathrm{~T}$ cells could therefore contribute to this failure, in addition to their possible exhaustion and/or anergy.

\section{REFERENCES}

1. Choudhary A, Davodeau F, Moreau A, Peyrat MA, Bonneville M, Jotereau F. Selective lysis of autologous tumor cells by recurrent gamma delta tumorinfiltrating lymphocytes from renal carcinoma. J Immunol. 1995;154:3932-40.

2. Kabelitz D, Wesch D, Pitters E, Zöller M. Characterization of tumor reactivity of human $\mathrm{V}$ gamma $9 \mathrm{~V}$ delta 2 gamma delta T cells in vitro and in SCID mice in vivo. J Immunol. 2004;173:6767-76.

3. Sicard H, Ingoure $S$, Luciani B, Serraz C, Fournié J-J, Bonneville $M$, et al. In vivo immunomanipulation of $\mathrm{V}$ gamma $9 \mathrm{~V}$ delta $2 \mathrm{~T}$ cells with a synthetic phosphoantigen in a preclinical nonhuman primate model. J Immunol. 2005;175:5471-80.

4. Rei $M$, Pennington DJ, Silva-Santos B. The emerging Protumor role of $\gamma \delta T$ lymphocytes: implications for cancer immunotherapy. Cancer Res. 2015;75:798-802.

5. Donia M, Ellebaek E, Andersen MH, Straten PT, Svane IM. Analysis of V $\delta 1$ T cells in clinical grade melanoma-infiltrating lymphocytes. Oncolmmunology. 2012;1:1297-304.

6. Wang J, Lin C, Li H, Li R, Wu Y, Liu H, et al. Tumor-infiltrating $\gamma \delta T$ cells predict prognosis and adjuvant chemotherapeutic benefit in patients with gastric cancer. Oncolmmunology. 2017;6:e1353858.

7. Groh V, Rhinehart R, Secrist H, Bauer S, Grabstein KH, Spies T. Broad tumorassociated expression and recognition by tumor-derived T cells of MICA and MICB. Proc Natl Acad Sci. 1999;96:6879-84.

8. Corvaisier M, Moreau-Aubry A, Diez E, Bennouna J, Mosnier J-F, Scotet E, et al. Vy9V82 T cell response to colon carcinoma cells. J Immunol. 2005;175:5481-8.

9. Sebestyen Z, Prinz I, Déchanet-Merville J, Silva-Santos B, Kuball J. Translating gammadelta $(\gamma \delta)$ T cells and their receptors into cancer cell therapies. Nat Rev Drug Discov. 2020;19:169-84.

10. Poupot $M$, Fournié J-J. Non-peptide antigens activating human $V \gamma 9 / V \delta 2 \mathrm{~T}$ lymphocytes. Immunol Lett. 2004;95:129-38.

11. Gober H-J, Kistowska M, Angman L, Jenö P, Mori L, De Libero G. Human T cell receptor $\gamma \delta$ cells recognize endogenous mevalonate metabolites in tumor cells. J Exp Med. 2003;197:163-8.

12. Hebbeler AM, Cairo C, Cummings JS, Pauza CD. Individual V V $2-J y 1.2+T$ cells respond to both isopentenyl pyrophosphate and Daudi cell stimulation: generating tumor effectors with low molecular weight phosphoantigens. Cancer Immunol Immunother. 2007;56:819-29.

13. Hoeres T, Holzmann E, Smetak M, Birkmann J, Wilhelm M. PD-1 signaling modulates interferon- $\gamma$ production by Gamma Delta $(\gamma \delta)$ T-cells in response to leukemia. Oncoimmunology. 2019;8:1550618.

14. Rossi C, Gravelle P, Decaup E, Bordenave J, Poupot M, Tosolini M, et al. Boosting $\gamma \delta \mathrm{T}$ cell-mediated antibody-dependent cellular cytotoxicity by PD-1 blockade in follicular lymphoma. Oncoimmunology. 2019;8:1554175.

15. Ono K, Onishi Y, Kobayashi M, Hatta S, Nasu K, Watanabe $S$, et al. $\gamma \delta$ T cell clonal proliferation early after PD-1 blockade. Ann Hematol. 2019;98:219-20.

16. Chauvin $C$, Joalland N, Perroteau J, Jarry U, Lafrance L, Willem C, et al. NKG2D controls natural reactivity of $\mathrm{V} \gamma 9 \mathrm{~V} \delta 2 \mathrm{~T}$ lymphocytes against mesenchymal glioblastoma cells. Clin Cancer Res. 2019;25:7218-28.

17. Chitadze G, Lettau M, Luecke $S$, Wang $T$, Janssen $O$, Fürst $D$, et al. NKG2D- and Tcell receptor-dependent lysis of malignant glioma cell lines by human $\gamma \delta \mathrm{T}$ cells: modulation by temozolomide and A disintegrin and metalloproteases 10 and 17 inhibitors. Oncoimmunology. 2016;5:e1093276.

18. Harly $C$, Guillaume $Y$, Nedellec $S$, Peigné $C-M$, Mönkkönen $H$, Mönkkönen J, et al. Key implication of CD277/butyrophilin-3 (BTN3A) in cellular stress sensing by a major human $\gamma \delta$ T-cell subset. Blood. 2012;120:2269-79.
19. Vantourout P, Laing A, Woodward MJ, Zlatareva I, Apolonia L, Jones AW, et al. Heteromeric interactions regulate butyrophilin (BTN) and BTN-like molecules governing $\gamma \delta T$ cell biology. Proc Natl Acad Sci USA. 2018;115:1039-44.

20. Karunakaran MM, Willcox CR, Salim M, Paletta D, Fichtner AS, Noll A, et al. Butyrophilin-2A1 directly binds germline-encoded regions of the $V_{\gamma} 9 \mathrm{~V} \delta 2 \mathrm{TCR}$ and is essential for phosphoantigen sensing. Immunity. 2020;52:487-98.e6.

21. Rigau M, Ostrouska S, Fulford TS, Johnson DN, Woods K, Ruan Z, et al. Butyrophilin $2 A 1$ is essential for phosphoantigen reactivity by $\gamma \delta T$ cells. Science. 2020;367. https://doi.org/10.1126/science.aay5516.

22. Sebestyen Z, Scheper W, Vyborova A, Gu S, Rychnavska Z, Schiffler M, et al. RhoB mediates phosphoantigen recognition by $\mathrm{V}_{\gamma} 9 \mathrm{~V} \delta 2 \mathrm{~T}$ cell receptor. Cell Rep. 2016;15:1973-85.

23. Rhodes DA, Chen H-C, Price AJ, Keeble AH, Davey MS, James LC, et al. Activation of human $\gamma \delta \mathrm{T}$ cells by cytosolic interactions of BTN3A1 with soluble phosphoantigens and the cytoskeletal adaptor periplakin. J Immunol. 2015;194: 2390-8.

24. Castella B, Kopecka J, Sciancalepore P, Mandili G, Foglietta M, Mitro N, et al. The ATP-binding cassette transporter $\mathrm{A} 1$ regulates phosphoantigen release and Vy9V82 T cell activation by dendritic cells. Nat Commun. 2017;8:15663.

25. Belmant $C$, Espinosa E, Halary F, Tang $Y$, Peyrat M-A, Sicard $H$, et al. A chemical basis for selective recognition of nonpeptide antigens by human $\delta$ T cells. FASEB J. 2000;14:1669-70.

26. Scotet E, Martinez LO, Grant E, Barbaras R, Jenö $P$, Guiraud M, et al. Tumor recognition following Vgamma9Vdelta2 $T$ cell receptor interactions with a surface F1-ATPase-related structure and apolipoprotein A-I. Immunity. 2005;22:71-80.

27. Manders EM, Stap J, Brakenhoff GJ, van Driel R, Aten JA. Dynamics of threedimensional replication patterns during the S-phase, analysed by double labelling of DNA and confocal microscopy. J Cell Sci. 1992;103:857-62.

28. Gan YH, Lui SS, Malkovsky M. Differential susceptibility of naïve and activated human gammadelta T cells to activation-induced cell death by T-cell receptor cross-linking. Mol Med Camb Mass. 2001;7:636-43.

29. Fisch P, Malkovsky M, Kovats S, Sturm E, Braakman E, Klein BS, et al. Recognition by human $V$ gamma $9 / \mathrm{V}$ delta $2 \mathrm{~T}$ cells of a GroEL homolog on Daudi Burkitt's lymphoma cells. Science. 1990;250:1269-73.

30. Gertner J, Wiedemann A, Poupot M, Fournié J-J. Human gammadelta T lymphocytes strip and kill tumor cells simultaneously. Immunol Lett. 2007;110:42-53.

31. Herrmann T, Fichtner AS, Karunakaran MM. An Update on the molecular basis of phosphoantigen recognition by V $ү 9 V \delta 2$ T cells. Cells. 2020;9. https://doi.org/ 10.3390/cells9061433.

32. Yang Y, Li L, Yuan L, Zhou X, Duan J, Xiao H, et al. A structural change in butyrophilin upon phosphoantigen binding underlies phosphoantigen-mediated Vү9V82 T cell activation. Immunity. 2019;50:1043-53.e5.

33. Dustin $M L$, Scotet $E$, Olive D. An X-ray vision for phosphoantigen recognition. Immunity. 2019;50:1026-8.

34. Lang F, Peyrat MA, Constant P, Davodeau F, David-Ameline J, Poquet $Y$, et al Early activation of human $\mathrm{V}$ gamma $9 \mathrm{~V}$ delta $2 \mathrm{~T}$ cell broad cytotoxicity and TNF production by nonpeptidic mycobacterial ligands. J Immunol. 1995;154: 5986-94.

35. Espinosa E, Belmant C, Pont F, Luciani B, Poupot R, Romagné $F$, et al. Chemical synthesis and biological activity of bromohydrin pyrophosphate, a potent stimulator of human gamma delta T cells. J Biol Chem. 2001;276:18337-44.

36. Martinet L, Fleury-Cappellesso S, Gadelorge M, Dietrich G, Bourin P, Fournié J-J, et al. A regulatory cross-talk between Vgamma9Vdelta2 $\mathrm{T}$ lymphocytes and mesenchymal stem cells. Eur J Immunol. 2009;39:752-62.

37. Martinet $L$, Poupot R, Mirshahi P, Rafii A, Fournié J-J, Mirshahi M, et al. Hospicells derived from ovarian cancer stroma inhibit T-cell immune responses. Int J Cancer. 2010;126:2143-52.

38. Tanaka Y, Morita CT, Tanaka Y, Nieves E, Brenner MB, Bloom BR. Natural and synthetic non-peptide antigens recognized by human gamma delta $T$ cells. Nature. 1995;375:155-8

39. Joseph N, Reicher B, Barda-Saad M. The calcium feedback loop and T cell activation: how cytoskeleton networks control intracellular calcium flux. Biochim Biophys Acta. 2014;1838:557-68.

40. Serrano R, Wesch D, Kabelitz D. Correction: Serrano, R.; Wesch, D.; Kabelitz, D. Activation of human $\gamma \delta$ T cells: modulation by toll-like receptor 8 ligands and role of monocytes. Cells 2020, 9, 713. Cells. 2020;9. https://doi.org/10.3390/ cells9091977.

41. Riganti C, Castella B, Massaia M. ABCA1, apoA-I, and BTN3A1: a legitimate ménage à Trois in dendritic cells. Front Immunol. 2018;9:1246.

42. Cabillic $F$, Toutirais $O$, Lavoué $V$, de La Pintière $C T$, Daniel $P$, Rioux-Leclerc $N$, et al. Aminobisphosphonate-pretreated dendritic cells trigger successful Vgamma9Vdelta2 $\mathrm{T}$ cell amplification for immunotherapy in advanced cancer patients. Cancer Immunol Immunother. 2010;59:1611-9.

43. D'asaro M, La Mendola C, Di Liberto D, Orlando V, Todaro M, Spina M, et al. V gamma $9 \mathrm{~V}$ delta $2 \mathrm{~T}$ lymphocytes efficiently recognize and kill zoledronate- 
sensitized, imatinib-sensitive, and imatinib-resistant chronic myelogenous leukemia cells. J Immunol. 2010;184:3260-8.

44. Sandstrom A, Peigné C-M, Léger A, Crooks JE, Konczak F, Gesnel M-C, et al. The intracellular B30.2 domain of butyrophilin $3 \mathrm{~A} 1$ binds phosphoantigens to mediate activation of human Vy9V82 T cells. Immunity. 2014;40:490-500.

45. Nguyen K, Li J, Puthenveetil R, Lin X, Poe MM, Hsiao CC, et al. The butyrophilin $3 A 1$ intracellular domain undergoes a conformational change involving the juxtamembrane region. FASEB J. 2017;31:4697-706.

46. Sireci G, Espinosa E, Di Sano C, Dieli F, Fournié JJ, Salerno A. Differential activation of human gammadelta cells by nonpeptide phosphoantigens. Eur J Immunol. 2001;31:1628-35.

47. Alcover A, Alarcón B. Internalization and intracellular fate of TCR-CD3 complexes. Crit Rev Immunol. 2000;20:325-46.

48. Nedellec S, Sabourin C, Bonneville M, Scotet E. NKG2D costimulates human V gamma $9 \mathrm{~V}$ delta $2 \mathrm{~T}$ cell antitumor cytotoxicity through protein kinase $\mathrm{C}$ thetadependent modulation of early TCR-induced calcium and transduction signals. J Immunol. 2010;185:55-63.

49. Efferth T. Adenosine triphosphate-binding cassette transporter genes in ageing and age-related diseases. Ageing Res Rev. 2003;2:11-24.

50. Perez J, Dansou B, Hervé R, Levi C, Tamouza H, Vandermeersch S, et al. Calpains released by $\mathrm{T}$ lymphocytes cleave TLR2 to control IL-17 expression. J Immunol. 2016;196:168-81.

51. Hafiane A, Genest JHDL. Atherosclerosis, and emerging therapies. Cholesterol. 2013:2013:891403.

52. Scotet $E$, Martinez LO, Grant E, Barbaras R, Jenö $P$, Guiraud $M$, et al. Tumor recognition following Vgamma9Vdelta2 $\mathrm{T}$ cell receptor interactions with a surface F1-ATPase-related structure and apolipoprotein A-I. Immunity. 2005;22:71-80.

53. Vantourout $\mathrm{P}$, Mookerjee-Basu J, Rolland C, Pont F, Martin H, Davrinche C, et al. Specific requirements for Vgamma9Vdelta2 $\mathrm{T}$ cell stimulation by a natural adenylated phosphoantigen. J Immunol. 2009;183:3848-57.

54. Favari E, Zanotti I, Zimetti F, Ronda N, Bernini F, Rothblat GH. Probucol inhibits ABCA1-mediated cellular lipid efflux. Arterioscler Thromb Vasc Biol. 2004;24:2345-50.

55. Delvecchio CJ, Bilan P, Nair P, Capone JP. LXR-induced reverse cholesterol transport in human airway smooth muscle is mediated exclusively by ABCA1. Am J Physiol Lung Cell Mol Physiol. 2008;295:L949-57.

56. Cubeddu LX. Drug-induced inhibition and trafficking disruption of ion channels: pathogenesis of QT abnormalities and drug-induced fatal arrhythmias. Curr Cardiol Rev. 2016;12:141-54.
57. Shi Y-Q, Fan P, Zhang G-C, Zhang Y-H, Li M-Z, Wang F, et al. Probucol-induced hERG channel reduction can be rescued by matrine and oxymatrine in vitro. Curr Pharm Des. 2020;25:4606-12.

58. Laplagne C, Meddour S, Figarol S, Michelas M, Calvayrac O, Favre G, et al. Vү9V $\delta 2$ T cells activation through phosphoantigens can be impaired by a RHOB rerouting in lung cancer. Front Immunol. 2020;11:1396.

\section{ACKNOWLEDGEMENTS}

This work was funded by INSERM, CNRS, the University Hospital of Bordeaux, and Toulouse III University. We acknowledge ImCheck for providing the 103.2 antibody and the 7.48 antibody. We are grateful to our healthcare professionals for their boundless efforts during the COVID-19 crisis.

\section{AUTHOR CONTRIBUTIONS}

$C$ Laplagne performed the experiments. $\mathrm{LL}$ and $\mathrm{FL}$ participated in the microscopic experiments. JJF, CLaurent and SV participated in the discussion of the results. JF reviewed the English language. MP and CLaplagne designed the experiments and wrote the paper. MP supervised the study.

\section{COMPETING INTERESTS}

The authors declare no competing interests.

\section{ADDITIONAL INFORMATION}

Supplementary information The online version contains supplementary material available at https://doi.org/10.1038/s41423-021-00720-w.

Correspondence and requests for materials should be addressed to M.P.

Reprints and permission information is available at http://www.nature.com/ reprints 